Jadila: Journal of Develomment and Innovation

in Language and Literature Education

Volume 1 Number 12020

Publisher: Yayasan Karinosseff Muda Indonesia

Page 69-84

\title{
The Derivational and Compounding Process in William Shakespeare's Literary Works
}

\author{
Rosalia Revita Cahyani \\ English Letters Department, Universitas Sanata Dharma \\ rosaliarevita9@gmail.com \\ Sara Immaculata Terra Istinara \\ English Letters Department, Universitas Sanata Dharma \\ terraistinara.11@gmail.com \\ Agnes Chika Damayanti \\ English Letters Department, Universitas Sanata Dharma \\ agneschika70@gmail.com \\ Kurniadining Sri Pertiwi \\ English Letters Department, Universitas Sanata Dharma \\ aniingksp@gmail.com \\ Corresponding author: rosaliarevita9@gmail.com
}

\begin{abstract}
One importance of studying morphology in literary work is increase the vocabulary. Perhaps the biggest contributions to the English language of Shakespeare may be the addition of new words and phrases that have transformed the language and make it more vivid and descriptive. Shakespeare also changing nouns into verbs, verbs into adjectives, connecting words never used together, adding affixes, and devising words wholly original. This study aims to know how the words are formed through derivational and compounding process. In this paper, researchers take the data from some of William Shakespeare's works. Researchers use qualitative method by using morphological approach to analyze the data. Morphological approach focused on the identification and interpretation of the meaning of the words and the analysis of the morphemes attached to the words. Researchers collect the data by downloading 11 of William Shakespeare's works, reading the words, selecting the data, and summarizing the data. Then, it's folloresearchersd by describing and determining the function of the morphemes and analyzing the change of the word class as techniques of analyzing the data. The result of this study shows that for derivational process, affix $\{$-ish $\},\{-y\},\{$-less $\},\{$-ate $\},\{$-eous \}, \{fore- $\},\{$ pur- $\}$, \{fore- $\},\{-y\}$, and $\{$ un- $\}$ as adjectivalizer, affix $\{-i f y\}$, \{en- $\}$, \{un- $\}$, and \{fore- $\}$ as verbalizer, and affix $\{-\mathrm{er}\},\{-\mathrm{y}\}$, and $\{-$ ment $\}$, as nominalizer. For compounding process, researchers found there are two types of compound word : hyphenated compound and closed compound.
\end{abstract}

Keywords: morphology, derivation, compound

\section{A. Introduction}

Language plays an important role in human's life as it is a tool to communicate among human. Language has communicative function that is used to transmit information (Brinton and Brinton, 2010, Diani, et al., 2019; Syafryadin, 2020; Syafryadin, et al, 2020; Noermanzah, et al., 2020). In a language, word is the fundamental basic as it is a key to communication. Tovar (2016) argues that no matter how researchersll students learn grammar 
or master the sound of the target language, without words to express meanings, communication cannot happen. There are many ways to expand our knowledge of words. One of them is by understanding morphological analysis. Morphology is the study of basic forms of words (Yule, 2010). Morphological analysis helps people to break down the morphemes and decode their meaning, and at the same time learning to form new words from the existing words by combining affixes and roots. One of sub-topics of morphology is word formation. It discusses how words are made through some processes, such as derivational and compounding process. Derivational process is attaching bound morphemes to a base to make a new word (Fromkin et al. 2011). Compounding process is joining two words to produce a single word (Yule, 2010). From here researchers can see that both derivational and compounding process analyze the basic forms of words and produce a new meaning from the existing words.

Morphology is usually defined as "the study of the internal structure of words and the rules governing the formation of words in a language" $(\mathrm{Oz}, 2014, \mathrm{p}$. 83). It refers to the mental system involved in word formation or to the branch of linguistics that deals with words, their internal structure, and how they are formed (Aronoff and Fudeman, 2011). The internal structure of words is morpheme (Brinton and Brinton, 2010). Morpheme is the smallest meaningful unit in a language (Rugaiyah, 2018). According to Martini (2016), morphemes can be classified into two: free morphemes and bound morphemes.

Free morphemes are those which can meaningfully stand alone as a word, while bound morphemes are morphemes which cannot meaningfully stand alone as a word. Thus, bound morphemes must be attached to other free morphemes. Bound morphemes are classified into two: inflectional and derivational. Inflectional morphemes do not create new meaning, while derivational is the opposite (Bauer, 1988). Sari (1988) says that derivational morphemes are bound morphemes which derive or create new words by either changing the meaning or the part of speech of the word or both. Derivational morphemes in English can be prefixes or suffixes (Martini, 2016). Unlike bound morphemes, free morphemes are those that can stand alone as word a word (Bishop, 2009). According Spencer and Zwicky (2017), if two free morphemes are joined together, they create a compound word. Both derivational and compounding process are parts of word formation in morphology.

The importance of this study is that researchers can understand how words are formed through derivational and compounding process. By studying the process of derivational and compounding, researchers can increase our vocabulary by combining morphemes easily to create new words and prepare ourselves to move onto the next level. Vocabulary is the 
collection of words that are known by a person (Linse, 2005). If researchers do not know any word and its meaning, researchers cannot arrange the words into sentences to be communicated. Vocabulary is also the basic development of all other skills of communication. According to Lado as cited in Mardianawati (2012: 11), vocabulary aspects involve meaning, spelling, pronunciation, word classes, and word use. Additionally, derivational and compounding processes also help students who face with unknown vocabulary. If they know the meaning of the root of the words and affixes, they will understand the word containing those word parts. Vocabulary is very important as words are the way how people understand others and express themselves in any language. Thus, understanding the analysis of words is needed. Students will know more words through affixation and combination of free morphemes which help them to communicate to each other.

Shakespeare's works are very famous. According to britishcouncil.org (2019), Shakespeare's works have been translated into more than 100 languages. Shakespeare's writings also contributed and influenced English language development in the 17th and 18th centuries. There researchersre more than 1700 words first used in Shakespeare's writing (shakespeare.org.uk, 2015). The language Shakespeare wrote during Elizabethan era, known as 'Early Modern English', is different from modern English nowadays. Therefore, it is interesting to analyze words in William Shakespeare's literary works.

This paper aims to investigate derivational affixes and free morphemes found in William Shakespeare's literary works. Then, it also aims to find the functions of both bound and free morphemes to form new words. Theoretically, the result of this study is expected to broaden our knowledge about derivational affixes and the combination of free morphemes in English words. While, practically, it is expected to function as an additional reference, guidance, or additional material for other researchers, especially students who want to investigate and know how to improve vocabulary from the existing words they find in books or literary works they read.

\section{B. Research Methodology}

In this research, researchers used qualitative method by using morphological approach to analyse the data. Qualitative research aims to criticize a non-numerical data as a humanistic or idealistic approach (Pathak et al. 2013). Researchers elected this method because all the data in this research is in the form of words which researchersre taken from some of William Shakespeare's literary works. 
Morphological approach is used to know root words and affixes to understand and recognize the meaning of the word (Wolf and Kennedy, 2003). Morphology explains the basis of our language system. Researchers would apply morphological approach by seeking the compound and derivational words. From our finding of those words, researchers would find the smallest units and the meaning of those words. Then, researchers would apply the approach to find the purpose of the morphemes found in the words in the literary works.

The data of this research is derivational and compound words that researchers found in some of William Shakespeare's literary works, which are Sonnet 4 (Unthrifty, Loveliness, Why Dost Thou Spend), Sonnet 8 (Music to Hear), Sonnet 16 (But Wherefore Do Not You a Mightier Away), Sonnet 25 (Let Those Who are in Favour with Their Stars), Sonnet 30 (When to the Sessions of Sresearcherset Silent Thought), Sonnet 55 (Not Marble, nor the Gilded Monuments), Sonnet 116 (Let Me not to the Marriage of True Minds), Troilus and Cressida: Act 3, Scene 3, and Antony and Cleopatra: Act 2, Scene 2.

In this study, researchers used several steps to collect the data. Firstly, researchers downloaded some of William Shakespeare's literary works from the researchers site https://www.folger.edu/shakespeares-works as researchers thought that this researchers site is credible and having complete William Shakespeare's literary works. Then, researchers read all the words in the literary works and search for the derivative and compound words. After researchers found the derivative and compound words, researchers select and identify the data by highlighting the data. Finally researchers summarize the data by making a table of the data based on the types of affixes for derivational process and content words for compounding process.

After the data have been collected, the data then researchers analysed through several steps. The first one, researchers described the derivational affixes and content words that researchers found in some of William Shakespeare's literary works. Secondly, researchers determined the function of the morphemes based on the categories of affixes from derivational affixes and words from content words in compounding process. Lastly, researchers made result based on our findings by breaking down the morphemes of each word and analysing the change of the word class.

\section{Results and Discussion}

\section{Results}

In this paper, we analyze the derivational and compound words that we found in some of William Shakespeare's literary works. The purpose of this paper is to reveal how the 
derivational and compound words in William Shakespeare's literary works are formed through affixation and combination of two free morphemes. Since we discuss two problems, we will divide the analysis and discussion of the problems into two parts. The first one is the analysis of derivational words and the second one is the analysis of compound words.

Table 1. Summary of Derivational Words in Shakespeare's Works

\begin{tabular}{|c|c|c|c|}
\hline No. & \multicolumn{2}{|c|}{$\begin{array}{l}\text { Types of Affixes of the Words and How the } \\
\text { Word Classes Change }\end{array}$} & \multirow{2}{*}{$\begin{array}{l}\text { Words } \\
\text { Sluttish }\end{array}$} \\
\hline \multirow[t]{10}{*}{1.} & \multirow[t]{10}{*}{ Suffix } & $\{$-ish $\}$ (noun - adj) & \\
\hline & & $\{-\mathrm{y}\}($ noun - adj) & Bloody \\
\hline & & $\{$-less $\}$ (noun - adj) & Dateless \\
\hline & & $\{$-ate $\}$ (noun - adj) & Temperate \\
\hline & & $\{$-eous $\}$ (noun - adj) & Beauteous \\
\hline & & $\{$-ify $\}$ (noun - verb) & Fortify \\
\hline & & $\{$-er\} (verb - noun) & \multirow[t]{2}{*}{ Mockery } \\
\hline & & $\{-\mathrm{y}\}($ noun - noun $)$ & \\
\hline & & $\{$-ment $\}$ (verb - noun) & \multirow[t]{2}{*}{ Impediments } \\
\hline & & $\{-\mathrm{s}\}$ & \\
\hline \multirow[t]{4}{*}{2.} & \multirow[t]{4}{*}{ Prefix } & $\{$ En- $\}$ (noun - verb) & Entomb \\
\hline & & $\{$ Fore- $\}$ (verb - verb) & Foregone \\
\hline & & $\{$ Pur- $\}($ adj - adj $)$ & Purblind \\
\hline & & $\{$ Mal- $\}$ (adj - adj) & Malcontent \\
\hline \multirow[t]{4}{*}{3.} & \multirow{4}{*}{$\begin{array}{l}\text { Confix } \\
(\text { Prefix }+ \text { Suffix) }\end{array}$} & $\{-\mathrm{y}\}$ (noun - adj) & \multirow[t]{2}{*}{ Unthrifty } \\
\hline & & $\{$ Un- $\}($ adj - adj) & \\
\hline & & $\{$ En- $\}$ (noun - verb) & \multirow[t]{2}{*}{ Enthroned } \\
\hline & & $\{-\mathrm{ed}\}$ & \\
\hline
\end{tabular}

Among those words, there are 18 affixes: nine affixes function as adjectivalizer, four affixes function as verbalizer, three affixes function as nominalizer, and two affixes which are not derivational affixes (inflectional affixes). Inflectional morphemes do not create new meaning. These morphemes never change the syntactic category of the words or morphemes to which they are attached (Bauer, 1988). Nevertheless, it gives grammatical information of the root. The derivational affixes mentioned before include five derivational affixes which do not change the part of speech of the base morphemes, as what have been stated by McGregor (2015) that affixes which are attached to a lexical root can result in a new word, but do not always change the part of speech of the root.

Apart from derivational morphemes found in Shakespeare's works, there are also found compound words even though the number of them are less than derivational ones. Below is the summary.

Table 2. Summary of Compound Words in Shakespeare's Works

\begin{tabular}{|l|l|l|l|}
\hline No. & \multicolumn{2}{|l|}{ Types of Word Classes of the Words } & Example \\
\hline 1. & Preposition + Verb & Out + live & Outlive \\
\hline 2. & Verb + Adj & Love + sick & Lovesick \\
\hline 3. & $\begin{array}{l}\text { Conjunction }+ \\
\text { Conjunction }\end{array}$ & Where + for & Wherefore \\
\hline 4. & Adjective + Adjective & Hind + most & Hindmost \\
\hline 5. & Adverb + Verb & Well + tuned & Well-tuned \\
\hline 6. & Adverb + Adjective & Forth + right & Forthright \\
\hline
\end{tabular}


There are only found six compound words in Shakespeare's works. Similar to derivational words, compound words in Shakespeare's works are also dominated by adjective.

\section{Discussion}

Derivational morphemes in Shakespeare's works occupy some different functions: adjectivalizer, verbalizer, and nominalizer. Each function is discussed below.

\section{Adjectivalizer}

Adjectivalizer is used to refer to adjective-forming affixes (Endley, 2010). It is the process when after comes the affixation, the part of speech of the base morpheme changes into adjective. It can also be defined as "any affix which produces an adjective from a noun, a verb, or another adjective" (Brinton and Brinton, 2010, p. 97). Based on the summary of the data, the affixes which function as adjectivalizer are $\{-$ ish $\},\{-y\},\{-\operatorname{less}\},\{$-ate $\},\{$-eous $\},\{$ pur- $\},\{$ mal- $\},\{-y\}$, and $\{$ un- $\}$.

\section{- $\quad$ Sluttish (Adj)}

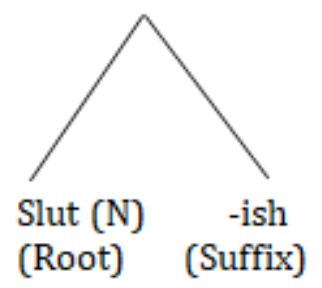

The derivational affix found in the word 'sluttish' is suffix $\{-\mathrm{ish}\}$. The root slut belongs to noun part of speech. Then, suffix $\{-\mathrm{ish}\}$ is attached to the root slut. This suffix changes the part of speech of the root from a noun to an adjective.

- Bloody (Adj)
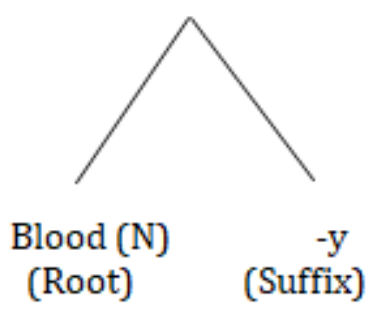

The derivational affix of the word 'bloody' is suffix $\{-y\}$. The root blood is a noun. Suffix $\{-y\}$ that is attached to the word 'blood' changes the part of speech of the root. It transforms the root which belongs to noun part of speech into adjective part of speech.

- Dateless (Adj)

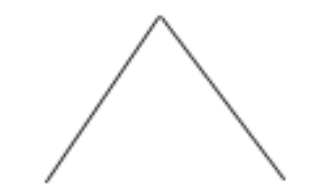

Date $(\mathrm{N}) \quad$-less

(Root) (Suffix) 
The derivational affix of the word 'dateless' is suffix $\{-$ less $\}$. The root date belongs to noun part of speech. Suffix $\{-$ less $\}$ that is attached to the root date modifies the part of speech of the root from a noun into an adjective.

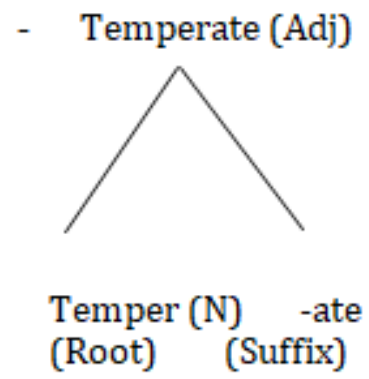

The derivational affix of the word 'temperate' is suffix \{-ate\}. The root temper is a noun. Suffix $\{-$ ate $\}$ that is attached to 'temper' changes the part of speech of the root from a noun into an adjective.

- Beauteous (Adj)

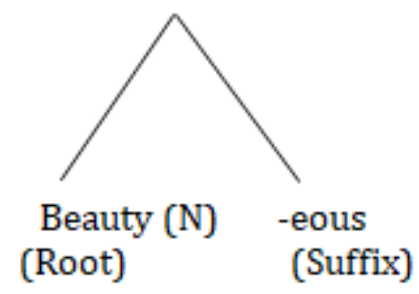

The derivational affix found in the word 'beauteous' is suffix \{-eous\}. The root beauty belongs to noun part of speech. Then, suffix $\{-$ eous $\}$ is attached to the root beauty. This suffix changes the part of speech of the root from a noun to an adjective. This word originates from Middle English. Nowadays, the word is often known as "beautiful."

- Purblind (Adj)
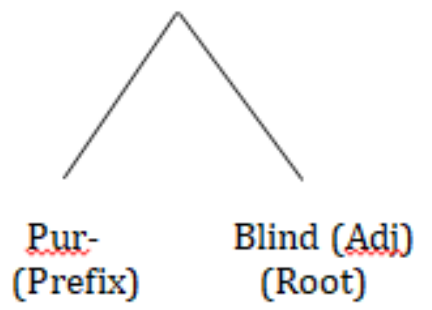

The derivational affix found in the word 'purblind' is prefix \{pur-\}. The root blind belongs to adjective part of speech. Then, prefix $\{$ pur -$\}$ is attached to the root blind. This suffix does not change the part of speech of the root because the word 'purblind' is also an adjective. 
- Malcontent (Adj)

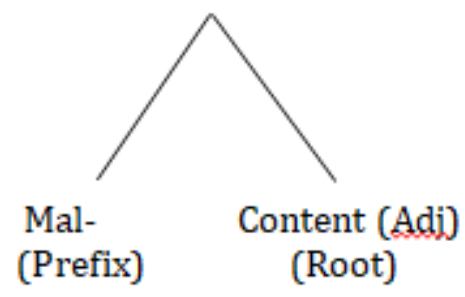

The derivational affix found in the word 'malcontent' is prefix \{mal-\}. The root content belongs to adjective part of speech. Then, prefix $\{$ mal- $\}$ is attached to the root content. This suffix does not change the part of speech of the root. However, it changes the meaning of the root from 'content' which means "satisfied" to 'malcontent' which means "unsatisfied."

- Unthrifty (Adj)

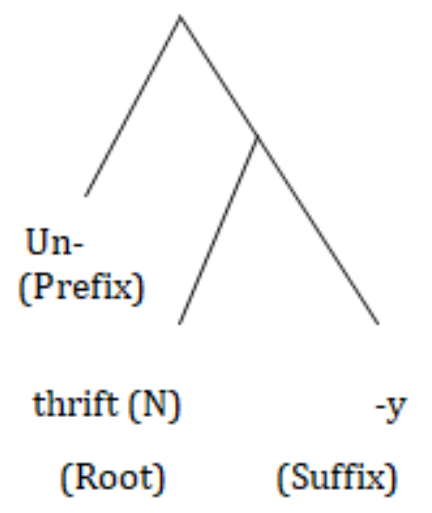

The derivational affixes found in the word 'unthrifty' are suffix $\{-\mathrm{y}\}$ and prefix $\{$ un -$\}$. The root thrift belongs to noun part of speech. Then, suffix $\{-y\}$ is attached to the root thrift. This suffix changes the part of speech of the root from a noun into an adjective. Then, prefix $\{\mathrm{un}-\}$ is attached to the word thrifty which then becomes unthrifty. This prefix does not change the part of speech of the word, but it changes the meaning of the word from 'thrifty' which means "showing a careful use of money" becomes 'unthrifty' which means "wasteful."

\section{Verbalizer}

Verbalizer is used to form verbs from other roots (Jackson and Amvela, 2000, p.76). It is also defined as a suffix which produces a verb from a noun or an adjective (Brinton and Brinton, 2010). Based on the summary of the data, the affixes which function as verbalizer are $\{$-ify $\},\{$ en- $\},\{$ fore- $\}$, and another $\{$ en- $\}$.

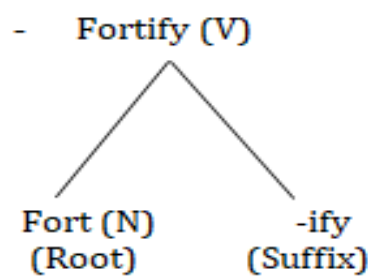


The derivational affix found in the word 'fortify' is suffix $\{-$ ify $\}$. The root fort belongs to noun part of speech. Then, suffix $\{-$ ify $\}$ is attached to the root fort. This suffix changes the part of speech of the root from a noun to a verb.

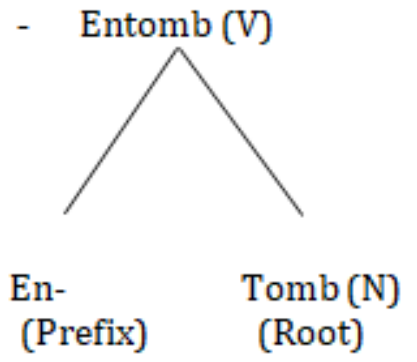

The derivational affix found in the word 'entomb' is prefix \{en-\}. The root tomb belongs to noun part of speech. Then, prefix $\{\mathrm{en}-\}$ is attached to the root tomb. This suffix changes the part of speech of the root from a noun to a verb.

- Enthroned (V)
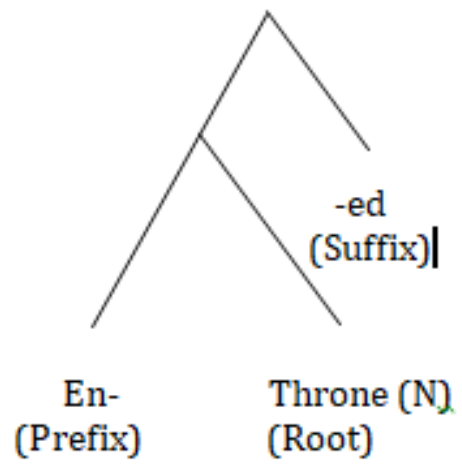

The derivational affix found in the word 'enthroned' is prefix \{en- $\}$. The root throne belongs to noun part of speech. Prefix $\{\mathrm{en}-\}$ changes the part of speech of the root from a noun into a verb. The reason why suffix $\{-$ ed $\}$ is not derivational affix is because it does not change the meaning or the part of speech of the root. However, suffix $\{-$ ed $\}$ changes the grammatical information of the root from present (enthrone) to past (enthroned).

- Foregone (V)

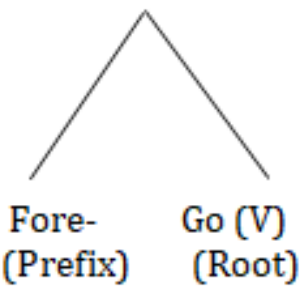

The word foregone is the past participle form of forego. The derivational affix found in the word 'forego' is prefix \{fore-\}. The root go belongs to verb part of speech. Then, prefix $\{$ fore -$\}$ is attached to the root go. This suffix does not change the part of speech because the word 'forego' is also a verb. 


\section{Nominalizer}

Any suffix which produces a noun is called nominalizer. This constitutes the largest set of class-changing suffixes (Brinton and Brinton, 2010). Based on the summary of the data, the affixes which function as nominalizer are $\{-\mathrm{er}\},\{-\mathrm{y}\}$, and $\{-\mathrm{ment}\}$.

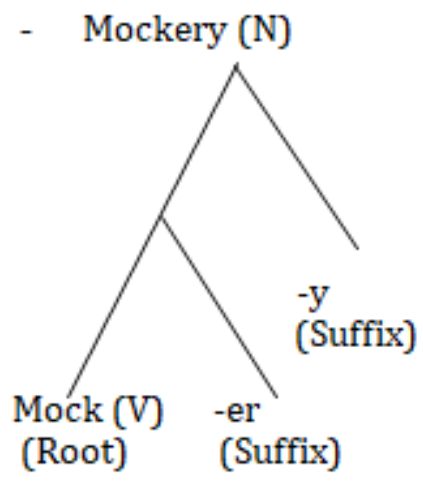

The derivational affixes found in the word 'mockery' are suffix $\{-$ er $\}$ and $\{-y\}$. The root mock belongs to verb part of speech. Then, suffix $\{-\mathrm{er}\}$ is attached to the root mock. This suffix changes the part of speech of the root from a verb to a noun. Then, suffix $\{-\mathrm{y}\}$ is attached to the word mocker which then becomes mockery. This suffix does not change the part of speech of the word, but it changes the meaning of the word from 'mocker' which means "the doer or the person who mock someone or something" becomes "mockery' which means "the act of mocking someone or something."

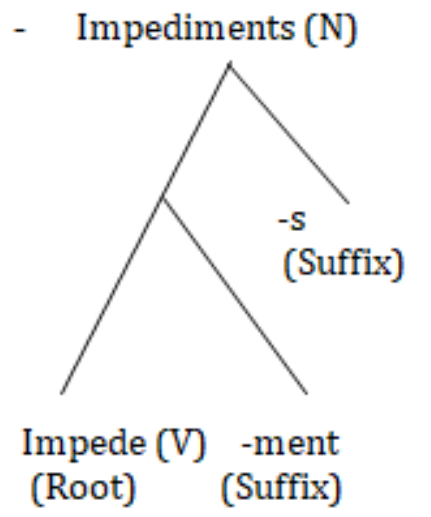

The derivational affix found in the word 'impediments' is suffix $\{-$ ment $\}$. The root impede belongs to verb part of speech. Then, suffix $\{-$ ment $\}$ is attached to the root impede. This suffix changes the part of speech of the root from a verb to a noun. Then, suffix $\{-s\}$ is attached to the word impediment which then becomes impediments. This suffix does not change the part of speech of the word, but it increases the number of the word from 'impediment' which means "one difficulty" becomes 'impediments' which means "many difficulties." 
While the derivational processes above are discussed in terms of the functions of derivational morphemes, the following part of compound words discuss the form of compounding: hyphenated and closed compound.

\section{Hyphenated Compound}

Hyphenated compound is a compound word that is combined using hyphens. A hyphenated compound is also called as a unit modifier. Hyphen is a mark of punctuation that not only unites but separates the component words; thus, it aids understanding and readability and ensures correct punctuation. Words are hyphenated mainly to express the idea of a unit and to avoid ambiguity (Magat, 2014). Based on the summary of the data we have well-tuned as an example for hyphenated compound.

- Well-tuned (Adj)

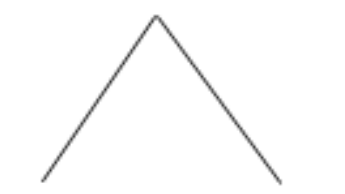

Well Tuned

(Adj) (Verb)

The word classes found in the word 'well-tuned' are adjective and verb. The word well belongs to adjective part of speech and the word tuned belongs to verb part of speech. The word tuned does not through derivational process since it comes from tune and suffix -ed. Suffix -ed is inflectional morpheme which only changes the grammatical information of the word tune from present to past. These words are then combined together become the word well-tuned which belongs to adjective part of speech. The word 'well' means "proper, in a good way" and the word 'tuned' means "to adjust in musical pitch or cause to be in tuned." However, if the words are combined together becomes 'well-tuned,' the meaning would be "properly pitched or tuned."

\section{Closed Compound}

In closed compound, the words combined are written as a single word. There are no hyphens or spaces between words in closed compound (Kavcic, 2004). In data analysis we have outlive, lovesick, wherefore, hindmost, and forthright.

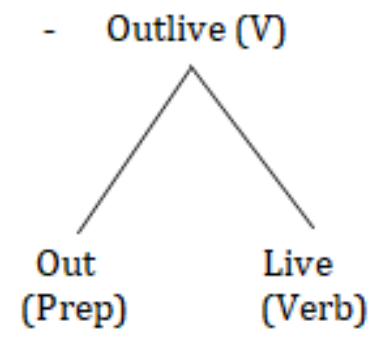


The word classes found in the word 'outlive' are preposition and verb. The word out belongs to preposition part of speech and the word live belongs to verb part of speech. These words are then combined together become the word outlive which belongs to verb part of speech. The word 'out' means "away from inside" and the word 'live' means "to be alive or have life." However, if the words are combined together become 'outlive,' the meaning would be "to exist or live longer than someone or something."

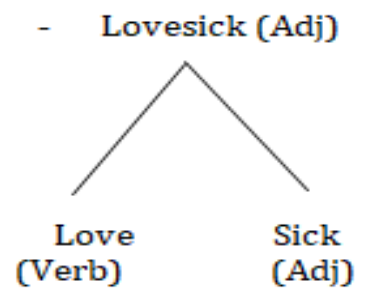

The word classes found in the word 'lovesick' are verb and adjective. The word love belongs to the verb part of speech and sick belongs to the adjective part of speech. Then, those two words are combined become one word, 'lovesick,' which belongs to adjective part of speech. The word love means "romantically and sexually attracted to someone," while the word sick means "physically or mentally ill." When those two words are combined become 'lovesick,' the meaning would be "sad because of love."

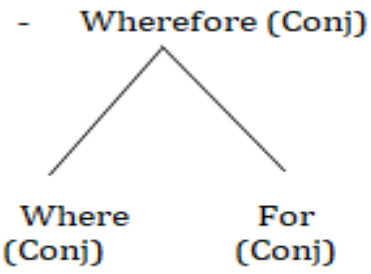

The word classes found in the word 'wherefore' are conjunction and adjective. The word where ("=what") belongs to conjunction part of speech and the word for also belongs to conjunction part of speech. These words are then combined together become the word wherefore which belongs to conjunction part of speech. It is quite difficult to explain how wherefore actually means "what for." Moreover, it is the combination of where which equalizes to what and for, not simply where and fore. Wherefore actually originates from Middle English wherfor, wherfore, or hwarfore. That is why if the word is broken down, we cannot associate where with "what" or for with "fore", as wherefore does not originate from English nowadays. In modern day, 'wherefore' is known as "why," means "for what reason or purpose."

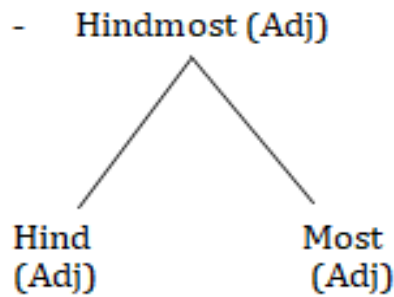


The word classes found in the word 'hindmost' are adjective and adjective. Both hind and most belong to adjective part of speech. These words are then combined together become the word hindmost which also belongs to adjective part of speech. The word 'hind' means "of or forming the part that follows or is behind" and the word 'most' means "greatest in quantity, extent, or degree." However, if the words are combined together become 'hindmost', the meaning would be "farthest to the rear".

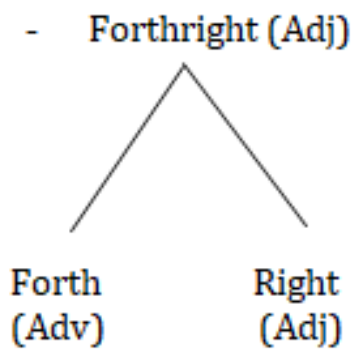

The word classes found in the word 'forthright' are adverb and adjective. The word forth belongs to adverb part of speech and the word right belongs to adjective part of speech. These words are then combined together becomes the word forthright which belongs to adjective part of speech. The word 'forth' means "onward in time, place, or order" and the word 'right' means "true/correct." However, if the words are combined together become 'forthright', the meaning would be "direct and honest in manner and speech."

\section{Conclusion and Suggestion}

The results of this study show that there are derivational and compounding processes that are used in some of the words in William Shakespeare's literary works. There are nine affixes function as adjectivalizer, four affixes function as verbalizer, three affixes function as nominalizer, and two affixes which are inflectional affixes. Based on the data, there are 2 types of affixes used: suffix and prefix. From our data, the affixes which function as adjectivalizer are prefix $\{$ pur- $\},\{$ mal- $\}$, and $\{$ un- $\}$ which do not change the part of speech of the roots, but change the meaning of the roots after the affixation and suffix $\{-$ ish $\},\{-$ less $\},\{-$ ate $\},\{$-eous $\}$, and $\{-y\}$ which transform the roots which belong to noun part of speech to adjective part of speech. The affixes which function as verbalizer are prefix $\{\mathrm{en}-\}$ and another $\{$ en- $\}$ along with suffix $\{$-ify $\}$ which transform the roots which belong to noun part of speech to verb part of speech and prefix \{fore-\} which does not change the part of speech of the roots, but change the meaning of the roots after the affixation. The affixes which function as nominalizer are suffix $\{-$ er $\}$, and $\{-$ ment $\}$ which transform the roots which belong to verb part of speech to noun part of speech and suffix $\{-y\}$ which does not change the part of speech of the roots, but change the meaning of the roots after the affixation. There are also affix which does not change the part of speech of the word, such as suffix \{-ed\} because it changes the grammatical information of the root from present (enthrone) to past (enthroned) 
and suffix $\{-s\}$ which increases the number of the word impediment which means "one difficulty" becomes the word impediments which means "many difficulties." Based on our data, there are two kinds of compound words: hyphenated compound and closed compound. Researchers found that there is one hyphenated compound that is combined using hyphens such as researchersll-tuned and five closed compounds which the words are written as a single word, such as outlive, lovesick, wherefore, hindmost, and forthright.

\section{References}

Aronoff, M., \& Fudeman, K. A. (2010). What is morphology?: Fundamentals of linguistics (2nd ed.). Chichester, UK: John Wiley \& Sons.

Bauer, Laurie. 1988. Introduction linguistic morphology. Edinburgh: Edinburgh University.

Bishop, Ashley. (2009). Vocabulary instruction for academic success. California: Shell Education.

Brinton, L. J., \& Brinton, D. M. (2010). The linguistic structures of modern English (Rev. ed.). Amsterdam, The Netherlands: John Benjamins B.V.

Diani, I., Yunita, W., \& Syafryadin, S. (2019). Interferensi bahasa Indonesia terhadap kemampuan berbicara bahasa Inggris mahasiswa Universitas Bengkulu. In Seminar Nasional Pendidikan Bahasa dan Sastra (pp. 164-173).

Endley, M. J. (2010). Linguistic perspectives on English grammar: a guide for Efl teachers. Charlotte, North Carolina, US: IAP, Information Age Publishing.

Estill, Laura and Johnson, E. (2015). British Council: Fun international facts about Shakespeare. Retrieved 2 June 2020 from https://www.britishcouncil.org/voicesmagazine/fun-international-facts-about-shakespeare.

Fromkin et al. (2011). An Introduction to Language. Canada: Cengage Learning.

Jackson, H. and Amvela, E.Z. (2000). Words, meaning and vocabulary: An introduction to modern English Lexicology. London, UK: Continuum International Publishing Group Ltd.

Kavcic, Andrej. (2004). Compounding. Ljubljana: University of Ljubljana.

Magat, J.A. (2014). Hawking hyphens in compound modifiers. Legal Communication \& Rhetoric: JALWD, 11, 153-175.

Mardianawati, L. (2012). Vocabulary teaching strategies used by teachers of junior high school (a descriptive study on private junior high school in Cilacap in academic year 2012/2013). Purwokerto:Muhammadiyah University of Purwokerto. 
Martini, I. D. A. K. (2016). Derivational of bound morpheme. International Research Journal of Management, IT and Social Sciences, 3(1), 15-22. Retrieved from https://sloap.org/journals/index.php/irjmis/article/view/343.

McGregor, W. B. (2015). Linguistics: An introduction (2nd ed.). London, UK: Bloomsbury Publishing Plc.

Mihalicek and Wilson. (2011). Language files: Materials for an Introduction to Language and Linguistics, 11th Edition. Ohio State University Press, Columbus.

Noermanzah, N., Syafryadin, S., Castrena, O. W., \& Abid, S. (2020). Rhetoric structure of the master of ceremony and the function of the akikah event in Lubuklinggau City. Journal of English Education and Teaching, 4(2), 232-247.

Noermanzah, Selbi Wahyuni, Tri Astuti, Dain E. C. Wardhana, and Syafryadin. 2020. "The Rhetorical structure of the Lubuklinggau mayor's speech in building community trust.” OSF Preprints. April 28. doi:10.31219/osf.io/j8p9t. International Journal of Progressive Sciences and Technologies (IJPSAT), 19(2), 146-154.

Oz, H. (2014). Morphology and implications for English language teaching. In A. Saricoban (Ed.), Linguistics for English language teaching studies (pp. 83- 120). Ankara: Ani Publishing.

Pathak, V., Jena, B., \& Kalra, S. (2013). Qualitative research. Perspectives in clinical research, 4(3), 192. https://doi.org/10.4103/2229-3485.115389.

Rugaiyah. (2018). Derivational and inflectional morphemes: A Morphological analysis. $J$ SHMIC (Journal of English for Academic), 5(2). https://doi.org/10.25299/jshmic.2018.vol5(2).1887.

Sari, N. (1988). An introduction to linguistics. Jakarta: Departemen Pendidikandan Kebudayaan.

Shakespeare Birthplace Trust. (2019). Shakespeare's words. Retrieved 2 June 2020 from https://www.shakespeare.org.uk/explore-shakespeare/shakespedia/shakespeares-words/.

Spencer, A., \& Zwicky, A.M. (2017). The handbook of morphology. Amsterdam, Netherlands: John Benjamins Publishing Company. DOI:10.1002/9781405166348.

Syafryadin, I. N. R., \& Widiastuti, R. (2013). Improving grade X students' speaking achievement under Round Robin technique. International Journal on Education, 1(1).

Syafryadin, Dian, E. C. Wardhana., Eka Apriani., \& Noermanzah. (2020). Maxim variation, conventional, and particularized implicature on students' conversation. International Journal of Scientific and Technology Research, 9(2) https://doi.org/10.31219/osf.io/cza8y.

Syafryadin, S. (2020). Students' Strategies in learning speaking: experience of two Indonesian schools. Vision: Journal for Language and Foreign Language Learning, 9(1), 34-47. doi:http://dx.doi.org/10.21580/vjv9i14791 
Tovar Viera, Rodrigo. (2016). The importance of vocabulary knowledge in the production of written texts: a case study on EFL language learners. Latacunga, Ecuador: Technical University of Cotopaxi.

Wolf, M., \& Kennedy, R. (2003). How the origins of written language instruct us to teach: A Response to Steven Strauss. Educational Researcher, 32(2), 26-30. https://doi.org/10.3102/0013189X032002026.

Yule, G. (2010). The study of language: Fourth Edition. New York: Cambridge University Press. 